\title{
ASPECTOS CULTURAIS NO ENSINO DE ALEMÃO COMO LÍNGUA ESTRANGEIRA: UMA ANÁLISE DE LIVROS DIDÁTICOS
}

\author{
Laura Janaina Dias Amato ${ }^{1}$
}

A presente dissertação resenhada teve como objetivo (a) analisar dois livros didáticos - THEMEN AKTUELL 1 e BERLINER PLATZ 1 - do ensino de alemão como língua estrangeira (LE), que segundo as editoras e os autores seguem as normas do Quadro Comum Europeu (QCE), sendo este elaborado com o intento de unificar o ensino das LEs na Europa e (b) comparar duas propostas de ensino de LE: uma nacional - Parâmetros Curriculares Nacionais (PCNs) e outra estrangeira - QCE.

Após a análise comparativa feita entre os livros didáticos chegou-se a conclusão que os aspectos culturais apresentados nos livros didáticos não suprem os PCNs ou o QCE, pois se nos primeiros temos uma maior valorização do ensino sobre a cultura, no segundo damos preferência a um ensino da cultura da língua-alvo.

Do estudo realizado, foi possível considerar que o papel da cultura acaba sendo fundamental não apenas para a compreensão lingüística, mas também para a formação e desenvolvimento do ser humano e, ao negar a importância da cultura, pode-se não só dificultar o acesso à informação, mas também desumanizar o homem, pois a cultura é humanizadora e libertadora, já que ela abre os horizontes e desenvolve o pensamento. FREIRE (2000) afirma que o acesso à informação é fundamental para que o homem tornar-se homem e libertar-se da opressão. O acesso à informação vai muito além do contato; também está relacionada à reflexão, à discussão e à transformação do ser humano. Nessa perspectiva freiriana, o docente deve "saber que ensinar não é transferir conhecimento, mas criar as possibilidades para a sua própria produção ou sua construção” (FREIRE, 2000, pág. 52). A mudança necessária para a transformação do homem é a mudança de mundo, sendo que ela “implica a dialetização entre a denúncia da situação desumanizante e o anúncio de sua superação, no fundo, o nosso sonho” (FREIRE, 2000, pág. 88). Essa perspectiva freiriana é a base da mesma educação multicultural pregada por TORRES (2001).

Os livros didáticos são meios importantes de transmissão cultural, mas não os únicos. Sozinhos não alcançam os objetivos pretendidos pelo QCE ou pelos PCNs, mas sim com a ajuda de um mediador, conforme defendido por VIGOTSKI (1998). O professor em um

\footnotetext{
${ }^{1}$ Laura Janaina Dias Amato é mestre em Letras. Atualmente é professora de Alemão no DELEM da UFPR.
} 
ensino intercultural não é só um mediador da língua, mas de tudo o que a engloba, como, por exemplo, a cultura. O papel do mediador cultural não termina com a transmissão dos aspectos enciclopédicos, como por exemplo, a capital ou os principais rios do país estrangeiro; isso o aluno pode adquirir sozinho. Os aspectos psicológicos, morais e comportamentais, que são geralmente apresentados de modo sutil, devem ser analisados e não exacerbados ou exaltados, pois, com isso, há o perigo de cair na caricatura, formando generalizações inadequadas. Mas não podemos esquecer que isso é praticamente impossível em um mundo globalizado, no qual as diferenças são minimizadas e, se o país se localiza na Europa, essas diferenças são mais sutis ainda devido à proximidade entre os países e o livre acesso dos cidadãos europeus dentro da União Européia (UE). Com a ajuda do QCE, a união entre os países tornou-se mais próxima, no que se refere à linguagem. Graças ao QCE, é possível ter um parâmetro igualmente estabelecido para todas as línguas da UE, caso alguém queira aprender uma das línguas pertencentes a esse grupo, já que o QCE não se aplica ao ensino de língua materna.

Porém, não podemos levar em conta somente o QCE, quando se trata de "união lingüística”, pois isso deve acontecer não segundo uma proposta, mas com a aplicação legítima do que foi pensado por diversos autores e verificando a sua veracidade na comunicação, ou seja, caso o QCE não seja respeitado, podemos formar alunos com habilidades e competências diferentes das por eles propostas. Aqui, podemos nos perguntar, mas será que queremos formar um cidadão conforme esses referenciais? Será necessário formar um indivíduo com padrões europeus? Qual função ele teria no contexto nacional? Será que o QCE é importante para o Brasil? Em que sentido? Estes questionamentos foram se desenvolvendo no decorrer deste trabalho. Nesse processo, conseguimos perceber que são indivíduos diferentes os que são formados segundo os critérios europeus, não são piores ou melhores, apenas diferentes, mas que não cabem na realidade brasileira, já que aqui não temos a fronteira livre com países falantes de diversas línguas, somente com países falantes de espanhol. Além disso, somente uma pequena parte da população faz fronteira com esses países, ou seja, somente uma parcela da população da região de fronteiras tem maiores chances de praticar todas as habilidades propostas pelo QCE. Não podemos esquecer que os aspectos culturais aqui são diversificados, pois variam conforme o país, isto é, o dia-a-dia na Argentina pode ser diferente do dia-a-dia na Venezuela, apesar dos dois países serem de língua hispânica.

Para o contexto brasileiro, é diferente formar um aluno com a mesma habilidade e saber intercultural de um aluno europeu, pois existem vários fatores que influenciam a aprendizagem que não foram abordados no QCE. Não podemos esquecer que o professor, ao sair da 
universidade, muitas vezes, não está preparado o suficientemente para assumir uma turma, a ele pode faltar tanto na área pedagógica quanto na área lingüística. O professor recém-formado pode não ter nível suficiente para ensinar, pois ele ainda é um aprendiz daquela língua. Classes lotadas, alunos desmotivados e a baixa carga horária que é oferecida para o ensino de língua estrangeira (varia entre 1-2 horas/semana). Isto não estimula o professor a passar algo extra ou a enxergar as entrelinhas que se escondem na lição de um livro que ele não escolheu. O professor precisa primeiro 'educar-se' culturalmente de forma adequadamente contextualizada, isto é, compreender criticamente as culturas com as quais ele trabalha, para então poder trabalhar seus conhecimentos de forma consciente com a percepção de que o que está sendo ensinado é UMA verdade, UM ponto de vista e não devem ser tidos como únicos.

Os livros analisados não preenchem todos os critérios necessários para formar um aluno, segundo os critérios europeus . Mas se não é um aluno com os moldes europeus o que pretendemos formar, será então que estes livros que não cumprem as normas do QCE podem ser utilizados em um contexto onde pretende-se ensinar sobre a cultura e não a cultura? Caso a resposta seja afirmativa, acreditamos então que há a possibilidade de aplicar esses livros no contexto nacional, porque é ensinar sobre a cultura o que os PCNs pretendem, diferenciandoos assim do QCE.

\section{REFERÊNCIA BIBLIOGRÁFICA:}

AUFDERSTRASSE, H.; BOCK, H.; GERDES, M.; MÜLLER, J.; MÜLLER, H. Themen 1 aktuell. München: Hueber, 2003.

BAKHTIN, M.(Volochinov) Marxismo e Filosofia da Linguagem. São Paulo: Hucitec, 2004.

FREIRE, P. Pedagogia da autonomia. São Paulo: Paz e Terra, 2000.

FONTES, S. M. Um lugar para a cultura. In: CUNHA, M.J.C.\& SANTOS, P.(orgs.). Tópicos em português língua estrangeira. Brasília: UNB, 2002, p. 175-183.

LEMCKE, C.; ROHRMANN, L.; SCHERLING, T. Berliner Platz 1. München: Langenscheidt, 2002. 
MENDES, E. Aprender a língua, aprendendo a cultura: uma proposta para o Ensino de Português Língua Estrangeira (PLE). In: CUNHA, M.J.C.\& SANTOS, P.(orgs.). Tópicos em português língua estrangeira. Brasília: UNB, 2002, p.185-199.

TORRES, C. A. Democracia, educação e multiculuralismo: dilemas da cidadania em um mundo globalizado. Petrópolis: Vozes, 2001.

VIGOSTKI, L. S. A formação social da mente. São Paulo: Martins Fontes, 1998. 